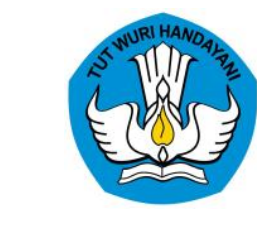

Check for updates

\title{
SHARING KNOWLEDGE: ARCHAEOLOGY AND EDUCATION IN THE MALUKU, INDONESIA
}

\author{
Marlon NR Ririmasse \\ Balai Arkeologi Maluku \\ J1. Namalatu-Latuhalat, Ambon 97118, Indonesia \\ marlon.ririmasse@kemdikbud.go.id
}

Received: 18/01/2018; revisions: 22/05 - 14/06/2018; accepted: 14/06/2018

Published online: $31 / 07 / 2018$

\begin{abstract}
Developing representational historical content for school curricula is a challenge in Indonesia. The wide range of ethnicities and cultural backgrounds in the country has created a unique education management situation. An unconventional approach emphasizing local content (muatan lokal) has been developed by the national government in the last two decades to address the demand for more representation of local issues in history and related subjects at schools. Despite this creative approach, the implementation of the program at the national level is still far from effective due to the underdevelopment of the concept and shortage of human resources. The participation of institutions, groups or individuals with the particular knowledge and expertise on local culture outside the formal educational institution has recently been adopted as a possible effective solution. This is a role in which archaeology might also make a positive contribution. This paper will discuss this issue by focusing on the contribution of archaeology to develop the local content in the education of Moluccas region in Indonesia. The discussion will include the examples of the program and project, which has been conducted in the last ten years.
\end{abstract}

Keywords: Archaeology; Education; Indonesia; Maluku

\section{INTRODUCTION}

There was an interesting experience when my institution conducted a public outreach program over three years ago. In the event entitled Archaeology Goes to School, we visited one of the high schools in the city of Ambon, Capital of Maluku Province, Indonesia. The presentation began with a display of a picture of the famous Borobudur temple in Indonesia and asking the students if anyone knew what the picture was. Simultaneously, almost all students are enthusiastically mentioned the name of the biggest temple in Indonesia. Next we presented a different image, this time a photo of a colonial fortress located near the school where the program was conducted. The location of the fortress was indeed relatively hidden in the densely populated area, but still should have been fairly well-known. But this time we did not heard the sound of enthusiasm. It was clear from the facial expressions of the students that they were searching for the right answer. No one knew the name of the fortress displayed, even though the distance was relatively close to the school. We faced the similar situation when we presented other images of heritage icons of Maluku. Only a few students responded, some of them by guessing.

This pattern is typical in our archaeology school visiting program. Students tend to have a better knowledge on the objects that represented national historical and cultural icons. In contrast, their knowledge of objects related to local cultural heritage seems very limited. Similarly, students tend to have a very limited information about the broader context associated with the knowledge of the local history, such as the history of the city. This gap of knowledge between the history and culture of national vs. local perspective is a common phenomenon found all over Indonesia. This condition is a consequence of managing a geographically vast country with a high diversity. This consequence is then reflected in the development of a well-balanced representative educational approach. On one hand, the education system is required to be able to develop curricula that represent Indonesia an entity. While on the other hand, the changing situation of the country with the rise of provincial autonomy has created the need for more locally-oriented educational materials. The 
implementation of the approach emphasizing local content (muatan lokal) has been seen as one of the possible solutions to address this specific need. Development of content designed from local sources, this particular knowledge might be adopted and presented as the teaching materials associated with the local condition. This teaching material is considered in line with the efforts to improve the sensitivity of the students to the condition and potential of the region where they are living.

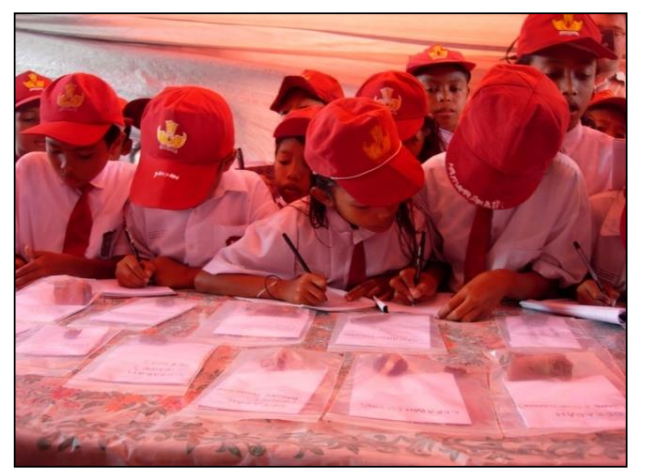

Figure 1. Elementary School Students visits Community Gathering and Exhibition in Ay Island, Banda

(Source: Tanudirdjo, 2007)

The concept of local content for Sedyawati (2007b: 5) might be seen as an effective solution that can not be addressed only by the formal educator. The idea of geographically-balanced materials offered by this local content approach is often constrained by the shortage of teaching materials and limited number of teacher with this specific knowledge and expertise. Our experience with the lack of knowledge of local history in the school visiting program reflects the obstacles of implementing this program at the school level. One of the possible solutions proposed by Sedyawati (2007a) is to legalize the participation of non-teacher individuals and institutions with the specific knowledge and expertise on the local culture and history, including, archaeological institutions and personnel. To implement the ideas above requires a relevant approach. Particularly on how to package all the archaeological knowledge in the form of local content as needed in Maluku. Based on this condition hence the question in this research is, 'How is the archaeological contribution to the development of local content in Maluku?'

Based on research question, the aim of this paper is to identify the contribution of archaeology in developing the concept of local content in the school curricula in the Moluccas, Indonesia.

\section{METHODS}

This paper is a conceptual review. Therefore fieldwork and literature studies have been adopted as the method for the paper. The literature sources used in this paper relate to the idea of developing local content in
Indonesia; public archeology; cultural resource management and references on Maluku archaeological sources.

\section{RESUlT AND DisCUSSION}

\section{Archaeology and Public: Paradigm Shift}

Communities in general usually understand that archaeology is a discipline related to knowledge of the past. Nevertheless, public understanding on the discipline, in particular is always varying. It is common for public to generalize everything related to the past as archaeology. For example, the fields of paleontology or history are often misunderstood as archaeology. This misinterpretation needs to be clarified. Although working in a multidisciplinary approach is normal to the discipline, archaeology's focus is on understanding the dynamics of culture in the past and all aspects surroundings, including social, economic, political, environmental relations and technology.

It was the interest in antiquity which has been accepted as the major factor behind the development of archaeology as a discipline. This passion was attached to the curiosity to explain the mystery behind the existence of the specific objects from the past. The activity gradually became more organized and later was developed into a field of study with its own scientific approach, methods and theories. After a long period of consistent development, archaeology has transformed into a discipline that uses knowledge of the past to answer present purposes. As a research-based discipline, archaeology is often misunderstood as study that merely serves scientific purposes, where all of knowledge obtained is mainly distributed internally or to related disciplines. In a scientific perspective this condition might be normally accepted, considering the academic realm where a dynamic discourse continually exists. Although this condition is positive on one side, on the other side it may misrepresent the position of archaeology as an exclusive discipline, without relevance to a wider public discourse (Tanudirdjo, 1995: 63).

The idea that archaeology has a larger role in society represents a widespread paradigm shift in archaeology. The emergence of new currents of thought as represented in the influence of postmodernism has also affected the behavior of archaeology as a discipline. The changing world situation of increased global connectivity has also been a trigger for change, allowing for the flow of knowledge and value to be transferred more easily across national borders. This change has also affected the way people view the past and its material remains. As David Lowenthal (1981: 213-237) stated, “...the past belongs to everyone; the need to return home, to recall the view, to refresh a memory, to retrace a heritage, is universal and essential...." Here, the knowledge of the past and all 
cultural heritage has been accepted as a heritage belonging to everyone. Hence, the responsibility for the preservation and management was understood as a mutual obligation as well.

This paradigm shift is also related to the growth of a new awareness in archaeology since three decades ago that recognizes that funding for research activities comes from the taxes paid by the public (Prasodjo, 2004). Therefore, archaeology has a responsibility to return its results and knowledge to the public. Here, public is no longer seen as an outsider, but rather as the true owner of archaeological resources and cultural heritage (Banks, 2006; Banks \& Banks, 2007; Blue et al., 2002; Cleere, 1984; Jameson, 2000: 288; Schofield, 2008: 25). Based on this paradigm shift, according to Tanudirdjo (2003) archaeology must reposition itself from the old position as legislator to a new role as mediator. The orientation of archaeology that based on the governmental function as the guard must be reviewed and repositioned in a new term as a steward (Fowler, 1982; Kohl \& Fawcett, 1995; Pearson \& Sullivan, 2013; Tanudirdjo, 1996; 2000; 2003). As a consequence, archaeology should develop the ability to identify the public interest on the knowledge of the past and cultural heritage (Australian Heritage Commission, 1998; McGimsey, 1991; 1977). This ability to identify the specific demand of the public is the major factor in the development of archaeology's contribution to the issue.

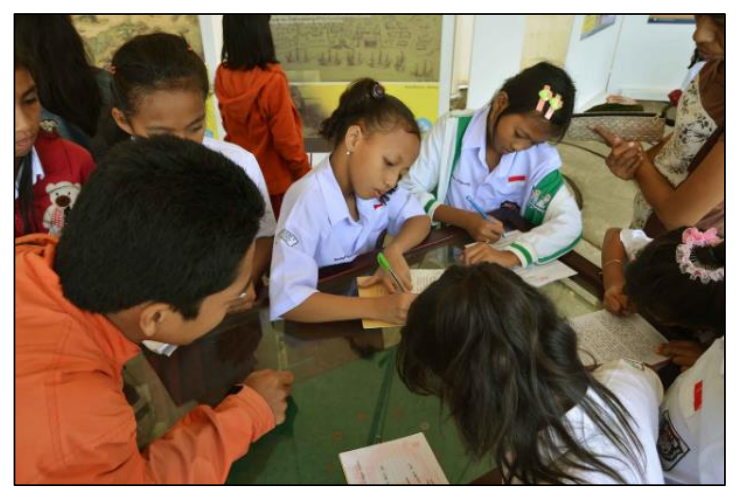

Figure 2. Elementary School visit Archaeological Exhibition in Ambon, Maluku

(Source: Balai Arkeologi Maluku, 2014)

\section{Local Content: Diversity as the National Character}

This wave of paradigm change also happened in Indonesia almost two decades ago. The fall of Soeharto government after more than 32 years in power has brought reformation in all areas of life in Indonesia. From politics to economy, education and culture, this new democratic climate has prompted new demands of policies that are more representative of local, periphery and minority interests. It was not surprising then to see that these new ideas of equality, diversity and the minority interests have grown in Indonesia. Initiated by the change of political system from the old centralistic style to the new more autonomous one, this transformation process extends to the educational system (Bjork, 2004).

The concept of so-called muatan lokal or local content is one representation of this transformation. Local knowledge is a subject in the Indonesia education curricula that related to the knowledge of specific regions in this country, particularly the region where students live and schools are situated. The term of locality in this perspective can include cities, counties or provinces. The character of the old curricula, which attempted to represent the diversity of Indonesia, has been seen as far from effective in representing locality. Students usually have a broad knowledge of national themes, but are very limited in term of local knowledge. Hence, locally-specific teaching materials have been developed as one of the solution. Beginning more than two decades ago, the concept of local content was driven by at least five factors: first, the implementation of regional autonomy; second, the decentralization policy, third, the multicultural character of Indonesia; fourth, the need to widen student knowledge on locality; and fifth, the need to develop a curricula that refers to the characteristics of local culture and support its sustainability. According to this background, the purpose of local content was always inherent in the effort to provide teaching materials that expand student knowledge about the local environment and culture. Included in this purpose are the specific targets that will encourage student abilities: first, to know and become more familiar with local nature and culture; second, to have provisional skills as well as knowledge on their locality that is useful for students and society in general; third, to develop an attitude and behavior that is consistent with local values; and fourth; to positively contribute in preserving and developing the value of local culture.

After more than two decades, the implementation of local content has had varying results. Several areas were able to accommodate the typical general aspects of local content, while some regions went further by successfully developing particular cultural content as teaching materials. However, it was clear as well that most regions still have not able to develop this concept due to number of factors. In the perspective of Sedyawati (2007a) this gap of implementation is closely related to the availability of teaching materials and the competence of teachers. Therefore, the participation of institution, groups and individuals outside the formal educational institution has recently been adopted as one of the possible solutions. It is indeed necessary for the education system to involve this non-teacher personnel with the specific knowledge and expertise on local issues to participate in developing the concept of local 
knowledge. Local artists, historians, farmers, fishermen, and elders are examples of local experts that might be able to contribute. This wider sphere of the concept of locality might sharpen into a form of thematic segments of local content (Macleod, 1977). Here, themes on local history and knowledge of local cultural heritage are areas where archaeology could positively contribute. The representation of archaeology in the content of national history, which is usually represented by famous national sites and iconic objects, can be augmented with local archaeological information. By using this model, the context of national cultural-historical issues might be positioned in a local perspective and vice versa.

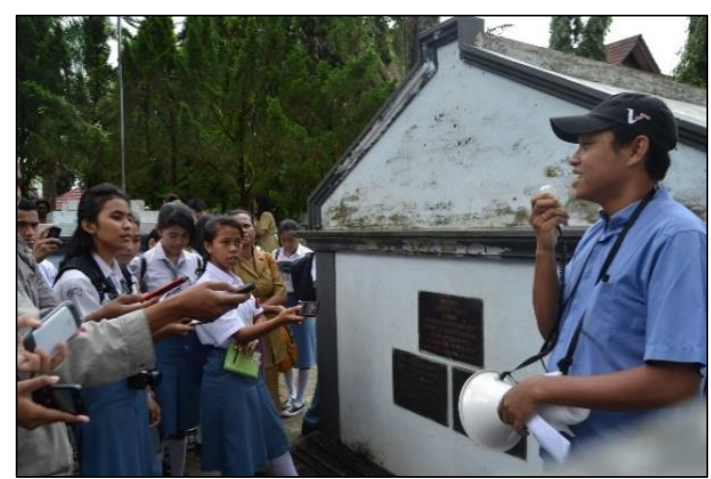

Figure 3. Archaeology and Urban Heritage Program for High School Students in Ambon, Maluku (Source: Balai Arkeologi Maluku, 2013)

\section{Archaeology in Maluku: The Setting}

Maluku is one of 34 Provinces in Indonesia. Currently, Maluku is a province with 2 cities and 9 districts. Ambon is the capital of Maluku province and also the largest city that serves as the center of government, economy, and education in Maluku. Universitas Pattimura which is the oldest and largest university in Maluku is also located in Ambon. The population of Maluku province in 2010 is 1.5 million. Maluku is one of the important region of Southeast Asia Cultural History. The islands are part of a biogeographic zone known as Wallacea. The area that separates Asia and Australia. Maluku is also an archipelagic region with the Banda Sea as one of the deepest sea in the world. With islands bordering the Australian Continent, this region is important in the geography of the region.

The Maluku Islands is one of the most important areas in the history of the world. In the past, this archipelago was known as the Kepulauan Rempah or The Spice Islands because of the Clove and Nutmeg plants which at that time only grew in this region. Cloves and nutmeg is a commodity sought by the Europeans; at the same time became one of the triggers of the growth of colonialism in the world (de Jonge \& van Dijk, 1995). The story of the Maluku spice in the civilization of the world actually has a much older story. Archaeological studies have shown evidence of the presence of the (clove) spice in Terqa, one of the regions of Syria estimated to date from $1700 \mathrm{BC}$ (Spriggs et al., 2005). It becomes a marker of Maluku islands contact with the vast world that has been so early. Historical sources of the world also have mentioned the Moluccas since the early BC. One of them is the Han Dynasty News from China that mentions the guests who want to meet the emperor should chew the cloves to have a fresh breath.

Despite having an important role in the history of the world, Maluku is one area that has not been studied from the perspective of cultural history studies. Including archaeology. According to Lape (2000a; 2000b) the geography of Maluku which is located far to the east, with the character of the islands that difficult to be accessed, was one of the reasons for the low interest of national academics to take part in this region at that time. At present, its condition is different. The increasing access to the Moluccas has made this region one of the areas referred for cultural history studies. Both by national researchers and foreign researchers. Includes academicians from archaeology discipline. This condition is deemed appropriate. Considering the historical role of Moluccas which is actually served for the rise of archeological studies in Indonesia. At that time Rumphius, a self-taught European scientist working for the VOC in Maluku, published his book D'Amboinsche Rariteitkamer or Chamber of Antiquities from Ambon (1705). In the book, among others, describes the unique-antique objects that was collected by Rumphius during his stay in Ambon. Includes the set of stone and metal artifacts. The work of Rumphius is accepted as the earliest academic source in Indonesia (and Southeast Asia) which examines cultural history and archaeology in Indonesia.

After Rumphius, the study of archeology in Maluku was derived from the personal records of European settlers living or serving in the Moluccas as Colonial Army, government officials, clergy, and scientists. One of them is Roder's (1937) writing on the rock art in Seram Island. After Roder's research, archaeological studies in the Moluccas vacuum for decades. Only in 1976, a research team led by Soegondho and Bintarti conducted an archaeological survey on the southern coast of Seram Island. In this study, the cave sites in the Amahai region was identified. Indications of prehistoric potential also arise with the discovery of the blade tool on the Rohowa site. The study conducted by Soegondho and Bintarti is the first study of national archaeologists in Maluku. The 1970s also marked the return of a group of foreign researchers conducting research in the Maluku region. Recorded names such as Spriggs and Miller are conducting an exploratory survey of the archaeological potential present in the Seram and Kei Islands regions (Spriggs \& Miller, 1988: 79-88; 1998: 49-62). In this study recorded sites such as Hatusua in West Seram; and the Heger Drum at Vaan for the first time. Figures like 
Glover and Ellen also conducted their research on Seram Island (Ririmasse, 2015c: 75-86).

During the 1990s archaeological studies found the momentum of its rise in Maluku following a long record of archaeological studies conducted over the decade. One of the research recorded is the University of Hawai' 'team and Universitas Pattimura joint research to review the use of the cave; diversity of substance and ethnoarchaeological study on the traditional community in Seram Island. This era also recognized activity of the Pusat Penelitian Arkeologi Nasional in conducting archeological studies in the region of Tehoru, on the South Coast of Seram Island led by Soegondho and Bintarti. The study was also conducted by Intan and Istari from Pusat Penelitian Arkeologi Nasional in observing the rock art painting site in Dudumahan, Kei Islands. Intan also identified and recorded the existence of a stone boat megalith monument at Sangliat Dol Site (Ririmasse, 2005: 35-55). One major archaeological research project in Maluku during the 1990s was represented by a three-year 1995-1997 study in the Aru Islands a joint research between the Pusat Penelitian Arkeologi Nasional and the Australian National University. The focus of this study is directed to several issues such as traces of maritime colonization and early settlers and interisland connectivity during the Pleistocene and early Holocene times; the introduction of agriculture and animal domestication as well as interactions between early settlers and Austronesian settlers; the role of Aru Islands as a supplier of birds of paradise and the variety of forest and sea products within 2000 years. The results of this three-season study have been published in The Archeology of Aru Islands, Eastern Indonesia (O'Connor et al., 2005: 19).

In 1999-2002 Maluku was hit by social conflict. The excess of these events also impact the archaeological research. When nearly a decade, the Moluccas closed to national and foreign researchers. Archaeological study activities during this uncertain period were conducted by Balai Arkeologi Maluku. At that time this institution was newly established and immediately had to face research activity in the unstable region. Balai Arkeologi Maluku (Ambon Archaeological Center) was established in 1995. This institution is the Technical Implementation Unit of the Ministry of Education and Culture. Establishment of this institute is intended to carry out archaeological research in the region of Maluku and North Maluku. Balai Arkeologi Maluku is one of ten institutions distributed throughout Indonesia. With this division expected, archaeological study activities in Indonesia can be more effective and provide comprehensive results.

The geographical condition of Maluku as an archipelagic territory with ninety percent of waters with more than a thousand islands is a natural challenge to be faced in the research process. This is then one of the considerations of the establishment of an archaeological research institution that specifically covers the region. Similarly, the biogeographical position of Maluku in the Wallacea zone is another consideration that makes this area necessary to be studied independently within a space framework. A complex ecological profile is a determinant of creating a culturally rich process. By these distinctive cultural history characteristics, Maluku has become an area that needs to be managed specifically within the framework of archaeological studies.

Since its founding more than two decades ago, the main research theme or highlight at the Balai Arkeologi Maluku is attached to colonial archeology. The selection of this theme seems to be attached to the fact that the Moluccan Islands have historically integrated with the history of spices and the beginning of colonialism. It can be observed from the colonial-era cultural products that are widely spread in these islands. Maluku is one of the areas in Indonesia with the largest amount of colonial forts. Unfortunately, despite the fact that it has been established as a major theme of regional research, it was not elaborated in detail about the aspects that were the goals and objectives of the research in the measured time frame. As a result, colonial archeology in Maluku has yet to provide findings and concepts that reflect its importance as a flagship theme. In addition to the colonial themes, Maluku also has a much more complex potential on other themes such as Islamic archeology and prehistory. This archipelago is home to some early Islamic kingdoms in the archipelago such as Ternate and Tidore. The two forces that became the lighthouse for the spread of Islam in the eastern archipelago. Prehistoric archeology is also a prospect. Considering the role of Maluku as part of Wallacea. A region with distinctive characteristics. Similarly, the islands' mound between Asia and Australia have a key role in explaining the complex process of human migration in the past (McKinnon, 1988; O'Connor et al., 2005; 2018; Ririmasse, 2010: 71-89; 2011: 23-38).

Based on the above conditions, where the complex profile of cultural history has intertwined with the vast landscape of regional geography, making attempts to manage archaeological studies in Maluku is a challenge. The prioritization of the research theme and key aspects studied are decisive in an effort to create an effective research strategy with maximum results. Shortly after Balai Arkeologi Maluku was established, the Pusat Penelitian dan Pengembangan Arkeologi Nasional (National Archaeological Research and Development Center, now the Pusat Penelitian Arkeologi Nasional) as the main institution has actually created thematic guidance on the aspects of common reference to national archaeological research. Known as the National Archaeological Research and Development Master Plan (RIPAN), the concept contains seven key themes that 
provide direction for archaeological research in Indonesia to achieve comprehensive national goals. The selection of themes and aspects reviewed, adjusting to the potential conditions and characteristics of the work area in each institution.

In its journey, RIPAN proved able to be a collective template that guides the direction of national archaeological research. Where the activities of archaeological studies conducted Pusat Penelitian Arkeologi Nasional and The Branch Offices (Balai Arkeologi) now have a guide that intertwine conceptually. The results in each work area are different, Since the aspects reviewed as well as its depth must vary from one work unit to another. What is then unfortunate is that with such positive progress, the large schemes represented in RIPAN seem to have never really reviewed the process and its achievements comprehensively. Included in the scope of Balai Arkeologi Maluku. Research activities are ongoing. Faithful in the corridors of routine. Therefore, although at a glance, it will be observed. So far reflecting on the research records that have been carried out, the issues covered for nearly two decades at each period in Balai Arkeologi Maluku can be divided according to several groups. The colonial issue as a highlight certainly dominates with the aspects reviewed: Contacts and early interactions with European settlers; The initial process of colonization and its social impact; Colonial economy: trade and spice monopoly; Materialization of the colonization process: colonial monumental trail; archeology of the colonial city. Islamic archeology as a periodization that is also associated with a relatively complex social structure has a diversity more or less similar to the colonial period. Where the aspects reviewed in the archaeological study record in Maluku include at least issues such as: The introduction and development of Islam in Maluku; Institutionalization of Islamic Institutions; Materialization of Islamic Culture; Islam in the footsteps of tradition. Prehistoric as the domain of the longest study of its time span and its potential, it can be said that it has not given maximum contribution in Maluku archaeological face. This is reflected in the scope of the study that is generally attached to an explorative approach with aspects that have not been directly proportional to the potential for prehistoric Maluku regionally. The scale of study is dominated by microsites; the blurring of the conceptual foundations underlying each study; lack of linkage to regional and regional-scale issues; the blurring of strategic research in the long term; as well as the weight of research that is still far from ideal is a parameter that becomes a benchmark of the condition concerned.

Observed chronologically it can be seen that the study activities are oriented on finding the traces of the oldest culture represented by Paleolithic technology until now has not been done independently by Balai Arkeologi. Observations on Paleolithic traces in the context of Maluku are represented by regional and national research results. Similar conditions are also found in the context of studies inherent in Neolithic culture. Identification of sites linked to the Austronesian-speaking migration process is also a contribution of active foreign researchers in Maluku (Ballard, 1988: 139-161). It is in the context of the late prehistoric times that the Balai Arkeologi Maluku has a real contribution to the knowledge of the region. As represented in the identification of various new findings characteristic of the iron-bronze culture spread throughout the region (Ririmasse, 2007a: 84-110; 2007b: 53-71; 2015b: 95112; 2016a: 179-201; 2016b: 1-12). Themes linked to prehistoric cultural footprints with independent research records for the Balai Arkeologi Maluku are more represented by aspects that link prehistoric culture in the form of a continuing tradition. In this context, the results of research are represented by traces of megalithic cultures that are still widely found in the daily lives of people in the region of the Islands. Local cultural practices that reflect past lifestyles are also aspects studied in the ethnoarchaeological framework. Here, the results of self-study at the Balai Arkeologi Maluku is quite extensive. Ethnography potential wealth in Maluku is a key aspect that gives positive impacts to ethnoarchaeology.

Beyond the set of issues embedded in the chronological framework above, there is another set of themes developed independently within the research context at the Balai Arkeologi Maluku. Some of the issues that have continued to develop over the last four years include archaeological studies in the boundary and the islands; maritime archeology; archaeological islands and coastal areas; as well as CRM with attention to archaeological contributions to local education (Retraubun, 2006: 6; Ririmasse, 2010: 71-89; 2012: 6074; 2013c: 71-88; 2015a: 73-88; Zuhdi, 2006: 7). Although this specific theme set is still in the initiation stage; but the idea originality that is in harmony with the characteristics and potential of the island-characterized region presumably provides a promising condition for future development.

\section{Archaeology as the Local Content: Implemen- tation in Maluku}

Maluku is a region with a specific character within Indonesia. Made up of almost one thousand islands, with more than ninety percent sea, the region can be seen as the smaller version of Indonesia. This geographical profile has created a challenge in managing the country, including the ability to manage the educational aspects. The main problem is usually the availability of sufficient teachers and teaching materials. The development of 
local content material as discussed above is also another recent challenge to be solved in the Indonesia education system. Based on our observation during the school visiting programs, the implementation of local content is still far from ideal. It was quite surprising that due to the lack of the materials, most of the schools have chosen English language materials for the local content classes. Teaching materials related to the cultural-historical aspects of Maluku is not yet accommodated as local content.

According to the teachers, the main problem for the implementation is the availability of ready-to-use material for local content. The specific characteristic of local culture and history are the major factor that obstructs the development of these materials. Schools may have teachers with expertise on the subjects of history and art. But to put it in the local context, their knowledge must be specific. This condition has created a gap to be filled. In terms of local content development, this might be contributed by people and institutions that have expertise and knowledge in local culture and history. Our institution, Balai Arkeologi Maluku, is one of the institutions that tries to contribute in the development of local content in the Moluccas. As the part of Ministry of Education and Culture, Balai Arkeologi Maluku is responsible to conduct the archaeological research in the provinces of Maluku and North Maluku. Its chronological scope range from prehistoric period to the more recent issues of ethnoarchaeology, but the research highlights for the region are associated with colonial archaeology, due to a large number of colonial remains in the area. Most of the research results are shared with the public, locally in Maluku and as well as nationally in Indonesia. The channels are varied, ranging from peer-reviewed scientific journals, websites and online publication to exhibitions, public discussions, school visits and a number of school-oriented programs.

Archaeology Goes to School is a brand name selected for the school-oriented dissemination programs carried out by our institution. First initiated ten years ago, the program recently has held eight to twelve events per year. The main targets for the program range from high school to elementary school. The area served is not only the capital of province (Ambon), but also smaller towns at the regency level, including in several outermost areas of Maluku (Ririmasse, 2005: 35-55; 2010: 71-89; 2011: 2338; 2013a: 25-38; 2013b: 71-88; 2016a: 179-201; 2016b: 1-12). If conditions allow it, public outreach programs are conducted in the research area or nearby site locations. The material presented in the program varies from oral presentation to simulations and participatory engagement. The content for the oral presentation normally includes an introduction to archaeology as a discipline and a short review of archaeological research in Maluku. In the simulation program, students are introduced to research activity from excavation to reconstruction and analysis. The broader use of research results is also presented to the students. The content includes the use for the educational purpose curricula and teaching materials. Often a popular icon related to archaeology is presented to assist student engagement. The research usually presented thematically in the chronological manner, from prehistoric to classical archaeology, Islam and colonial period of Indonesian historical periodization. The cultural remains of every period are generally presented in terms of historical and archaeological national framework. Later, they are contextualized with the similar objects and sites in Maluku.

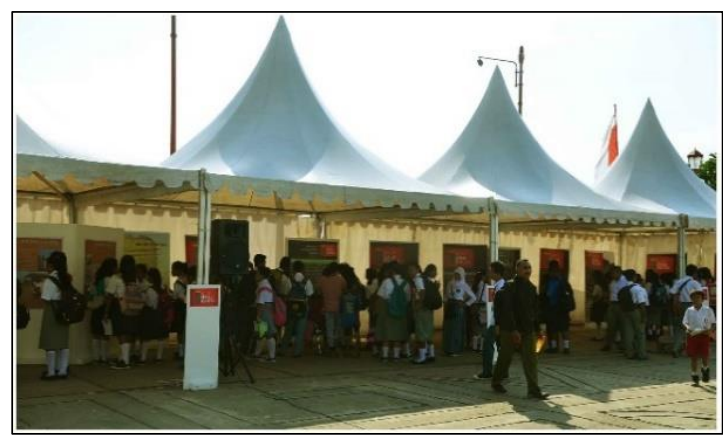

Figure 4. Archaeological Exhibition visited by Students in Ambon, Maluku

(Source: Balai Arkeologi Maluku, 2014)

Locality is the major factor in considering issues and material for the events. If the program is conducted in the capital of province, the material presented will be driven by issues related to the historic-colonial city of Ambon. Often, if the data is available, historic documentation of the area nearby the school is presented. If the program are conducted in the regency level in the outer areas of Maluku, research results and archaeological potential of the area will be presented to give local content. In particular, for the dissemination program conducted in a research area or near an archaeological site, the approach usually consists of site visits and open exhibitions. Often student are invited and encouraged to actively participate

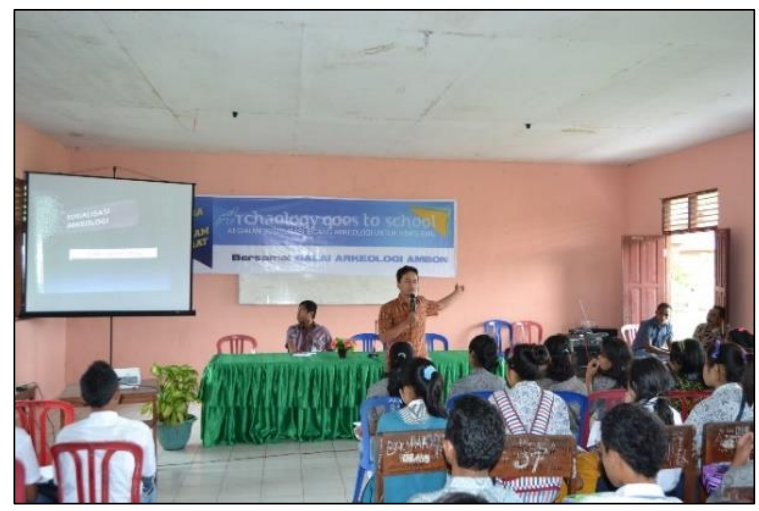

Figure 5. Archaoelogy Goes to School Program (Source: Balai Arkeologi Maluku, 2012) 
in the research process and can actively interact with the archaeologists. So far, the program has been positively received by students and schools. Archaeology as a discipline is to some extent attractive for the public. Schools and teachers are usually very enthusiastic since the material presented consists of local content that has not been found previously in the formal nationally-based educational references. The presence of archaeological dissemination programs is seen as a medium in which to learn local history and culture in which never been presented before in formal school curricula.

Critical input has also been received. Typical comments are requests to increase the frequency and duration of the dissemination program. Suggestions also include requests for student-friendly publication material, as well as providing more online knowledge of archeology in Maluku.

\section{Discussion: Developing a New Approach for the Dissemination of Local Content}

Since the implementation over more than ten years, archaeological dissemination activities in Maluku need to be reviewed and improved. The efforts are directed toward developing more effective local content material by using school-friendly archaeological dissemination approaches, including helping students and teachers to have a better knowledge about the cultural history of Maluku. Based on input that we have received over ten years, the improvements will be focused on five aspects: first, the development of content themes; second, the construction of more interactive dissemination approaches; third, regular renewal the dissemination materials; fourth, increasing the frequency of programs; fifth, initiating coaching program for school teachers.

First, the development of themes and content is intended to create more student-friendly teaching materials. The material using for the program should be easy to be understood at every level of school. One of the solutions that could be implemented is to link this specific knowledge of local content with the main subjects at school. History, geography, physics, biology, mathematics and even moral education could be accommodated. On the subject of history, it is possible to correlate the issue at the regional and national level with the events, sites and objects in the local context. Here, the major themes in the national history books could be compared in terms of local ones. For example, for the prehistoric period, Paleolithic and Neolithic objects in the Indonesian context can be compared with similar objects from Maluku. The material culture of the Paleometallic period that has been found extensively in the southeast Moluccas could be compared with related objects at the national and regional level. Similar approaches could be applied to rock art sites. Imprints of Hindu and Buddhist cultures (which some claim do not exist in the Moluccas) have been identified in North and Southeast Maluku. Rich with Islamic and colonial period heritage, it will be effective to compare Maluku to other regions. Geography could be associated with the cultural characteristics of each group of islands in Maluku or by describing the condition of paleogeography of the area. Biology can be included in terms of the distinctive character of Maluku as the part of the transitional Wallacea zone and how this environment has affected the cultural development of the region. It is possible as well to accommodate the knowledge of the endemic clove and nutmeg plants in a historical context. The subject of character building can be attributed to local philosophical values and wisdom attached to the archaeological objects in Maluku. Object such as dolmen and related megalith structures for example, are always attached to the value of unity and togetherness. This complexity of cultural heritage in Maluku could also provide diversity education for students (Ririmasse, 2008: 142-157).

Second, the need for the development of more interactive dissemination programs is a challenge as well. So far, the method has been dominated by in-class teaching approaches. A more participatory approach such as site visits has not been conducted very often. Here, the development can be implemented by increasing the frequency of site visits and encouraged the participation of students and schools near the research locales. The simulation of archaeological excavation can be carried out in the field or in open-air exhibition programs. Student could also participate in identifying artifacts such as lithics and ceramics as well as reconstructed pottery. Archaeological documentary films and discussion would be another alternative approach for students.

Third is developing the more effective teaching materials. So far, the materials presented in the dissemination program tend to be very modest in the form of presentation and printed materials. Here, improvements can be made by developing more attractive packaging for students such as digitized materials. This could include a short documentary movie that could be developed with the local government.

Fourth is to increase the frequency of the dissemination program. Recently, the archeological dissemination program in our institution is up to eight times per year. Mostly it is conducted in schools and in various regions of Maluku. However, to increase the frequency we will need to coordinate with other programs in the institution that are scheduled yearly. The most acceptable solution is probably by developing inresearch site visits and discussion. Another option is to encourage archaeologists personally to contribute to particular subject in class through the arrangement with schools. 
Fifth is to coach the teachers of the related subjects on the particular knowledge of archaeology and culture in Maluku. One option is to develop and publish schoolfriendly archaeological references for teachers, including references that relate to local history and its association to national and wider contexts. Encouraging teachers to participate in research, training and seminars in a limited context is also possible. This approach might serve as a vehicle to develop interest, knowledge and competence of teachers as one of the main actors in the implementation of local content.

Of course, the success of development of local content could be achieved by synergizing all of the stakeholders and parties involved. This includes national and local governments, schools, teachers, students and the people and institutions with particular expertise on local culture and history, including archaeological institutions and experts. This synergy could be achieved by developing positive communication and collaboration among stakeholders. It is our certain goal that with the contribution of archaeology, the development of local content could be successfully implemented to have a more equal education in Maluku and Indonesia.

\section{Conclusion}

Managing diversity is one of the keywords in the nation-building of Indonesia. The multicultural characteristic of the country is an issue that needs proper management to accommodate various interests. This includes the education issue where there is high demand to synchronize the nationally-based teaching materials with the specific local themes. The implementation of the local content is seen as one of the ideal solution for the problem, particularly to provide material related to local culture for students.

In the twenty years since initiation, local content has become a relatively effective approach in presenting local-based knowledge for students, though with varying results. The major obstacles came from the availability of ready-to-use teaching materials and the competence of the teachers. Encouraging the participation of people, groups and institutions with expertise and knowledge related to the local culture has been accepted as a solution. Particularly in the context of cultural-historical study, archaeology is one of disciplines that could positively contribute to the development of local content.

As the part of Indonesia, Maluku is a region that is characterized by cultural pluralism. The region also faces the same challenges as other areas in the country, where gaps exist between the knowledge of national history and the knowledge of the past in the local context. Archaeological dissemination to schools has been adopted as one of the solutions that positively contributed to solving the issue. Here, the knowledge of local culture and history is attached to and compared with the context of history in the national curricula. The program has been conducted using the brand Archaeology Goes to School and has included school visits, exhibitions, contests, simulations, site visits, and participatory in-field research.

The program has been received very positively by educational stakeholders in the region. Comments and suggestions include requests to increase the frequency of the program as well as the geographical coverage. Therefore, the possible development plan in the near future might include several aspects: first, the development of more school-friendly teaching materials; second, to create of more interactive dissemination program; third, presenting more effective teaching materials; fourth, to increase the frequency of dissemination program and coverage; fifth, by developing the competence of teachers on the related issue and materials of local content.

\section{ACKNOWLEDGEMENT}

I would like to express my gratitude for Prof. Peter Lape from the University of Washington for read the draft and provided insight that greatly assisted this paper. I also thank Forum Peneliti Kemdikbud in Lombok Workshop who share their thoughts and inputs for the early concept of this paper.

$$
* * * * *
$$

\section{REFERENCES}

Australian Heritage Commission. (1998). Protecting Local Heritage Places. Canberra: Australian Heritage Commission.

Ballard, C. (1988). Dudumahan: a rock art site on Kai Kecil, Southeast Mollucas. Bulletin of the Indo-Pacific Prehistory Association, 8, 139-161.

Banks, J. A. (2006). Race, culture, and education: the selected works of James A. Banks. New York: Routledge.

Banks, J. A., \& Banks, C. A. M. (2007). Multicultural education: issues and perspectives. Hoboken: Wiley.

Bjork, C. (2004). Decentralisation in Education, Institutional Culture and Teacher Autonomy in Indonesia. International Review of Education, 50(3-4). 245-262.

Blue, G., Bunton, M., \& Croizier, R. (2002). Colonialism and the Modern World: Selected Studies. Armonk NY: M.E. Sharpe.

Cleere, H. (1984) World cultural resource management: problems and perspectives. In H. Cleere (Ed.), Approaches to the Archaeological Heritage: A Comparative Study of World Cultural Resource Management System (pp. 125-131). Cambridge: Cambridge University Press.

De Jonge, N., \& van Dijk, T. (1995). Forgotten Islands of Indonesia: The Art and Culture of the Southeast Moluccas. Singapore: Periplus.

Fowler, D. (1982). Cultural Resources Management. Advances in Archaeological Method and Theory, 5, 1-50. 
Jameson Jr, J. H. (2000). Public interpretation, education and outreach: the growing predominance in American archaeology. In A. Hatton, \& F. P. McManamon (Eds.), Cultural Resource Management in Contemporary Society: Perspective on Managing and Presenting the Past (pp. 288-299). London: Routledge.

Kohl, P. L., \& Fawcett, C. (1995). Nationalism, politics, and the practice of Archaeological. London: Cambridge University Press.

Lape, P. V. (2000a). Contact and Conflict in the Banda Islands, Eastern Indonesia, 11th to 17th Centuries. Dissertation Brown University, Rhode Island.

Lape, P. V. (2000b). Political Dynamics and Religious Change in the Late Pre-colonial Banda Islands, Eastern Indonesia World Archaeology, 32(1), 138-155.

Lowenthal, D. (1981). Conclusion: dilemmas of preservation. In D. Lowental, \& M. Binney (Eds.), Our Past Before Us, Why Do We Save It? (pp. 213-237). London: Tample Smith.

Macleod, D. G. (1977). Peddle or perish: archaeological marketing from concept to product delivery. In M. B. Schiffer, \& G. J. Gummerman (Eds.), Conservation Archaeology. New York: Academic Press.

McGimsey, C. R. (1991). Protecting the Past: Cultural Resource Management, A Personal Perspective. In G. S. Smith, \& J. E. Ehrenhard (Eds.), Protecting the Past (pp. xvii-xxiii). Boca Raton: CRC Press.

McGimsey, C. R. (1977). The management of archaeological resource, the Airlie House Report. Washington D.C.: Society for American Archaeology.

McKinnon, S. (1988). Tanimbar Boats. In J. P. Barbier, \& D. Newton (Eds.), Islands and Ancestors: Indigenous Styles of Southeast Asia (pp. 152-169). New York: The Metropolitan Museum of Art.

O'Connor, S., Spriggs, M. Veth, P. (2005). The Aru Island in Perspective. In S. O'Connor, M. Spriggs, P. Veth (Eds.), The Archaeology of the Aru Islands, Eastern Indonesia. Canberra: Pandanus Books.

O'Connor. S, Mahirta, Tanudirjo, D., Ririmasse, M., Husni, M., Kealy, S., Hawkins, S., Alifah. (2018) Ideology, Ritual Performance and Its Manifestations in The Rock Art of Timor Leste and Kisar Island, Island Southeast Asia. Cambridge Archaeological Journal, 28(2), 225-241.

Pearson, M., \& Sullivan, S. (2013). Looking after heritage places. Melbourne: MelbourneUniversity Press.

Prasodjo, T. (2004) Arkeologi dan Pemberdayaan Masyarakat Lokal. Buletin Cagar Budaya, 2.

Retraubun, A. (2006, September 20). Mengapa Terluar bukan Terdepan. Kompas, p. 6.

Ririmasse, M. (2005). Jejak dan Prospek Penelitian Arkeologi di Maluku. Kapata Arkeologi, 1(1), 35-55.

Ririmasse, M. (2007a). Penelitian Arkeologi di Desa Lingat Pulau Selaru Kabupaten Maluku Tenggara Barat. Berita Penelitian Arkeologi Balai Arkeologi Maluku, 3(4), 84110.

Ririmasse, M. (2007b) Fragmen Moko dari Selaru: Temuan Baru Artefak Logam di Maluku. Berita Penelitian Arkeologi Balai Arkeologi Maluku, 3(5), 53-71.

Ririmasse, M. (2008). Visualisasi Tema Perahu dalam Rekayasa Situs Arkeologi di Maluku. Naditira Widya, 2(1), 142-158.

Ririmasse, M. (2010). Arkeologi Pulau-pulau Terdepan di Maluku, Suatu Tinjauan Awal. Kapata Arkeologi, 6(10), 71-89.

Ririmasse, M. (2011). Arkeologi Kawasan Tapal Batas: Koneksitas Kepulauan Maluku dan Papua. Papua: Jurnal Penelitian Arkeologi Papua dan Papua Barat, 3(1), 23-38.
Ririmasse, M. (2012). Laut untuk Semua: Materialisasi Budaya Bahari di Kepulauan Maluku Tenggara. AMERTA, 30(1), 60-74.

Ririmasse, M. (2013a). Materialisasi Identitas: MonumenMonumen Perahu Batu di Kepulauan Tanimbar. AMERTA, 31(1), 25-38.

Ririmasse, M. (2013b). Arkeologi Pulau Terluar di Maluku: Survei Arkeologi Pulau Masela. KALPATARU, 22(2), 71-88.

Ririmasse, M. (2013c). Pelayaran dan Perdagangan Masa Lalu di Kepulauan Maluku Tenggara. KALPATARU, 22(1), 31-42.

Ririmasse, M. (2015a) Pusaka Budaya Kawasan Pesisir: Tinjauan Arkeologis atas Potensi di Kepulauan Maluku. KALPATARU, 24(2), 73-88

Ririmasse, M. (2015b). Biografi Budaya Bendawi: Diaspora Nekara Perunggu di Kepulauan Maluku. Berkala Arkeologi, 35(2), 95-112.

Ririmasse, M. (2015c). Abad Baru Purbakala: Memilih Arah Menentukan Peran Penelitian Arkeologi di Maluku. Kapata Arkeologi, 11(2), 75-86.

Ririmasse, M. (2016a). Arkeologi Pulau Terdepan: Tinjauan Potensi Purbakala di Pulau Selaru Maluku Tenggara Barat. Papua: Jurnal Penelitian Arkeologi Papua dan Papua Barat, 8(2), 179-201.

Ririmasse, M. (2016b). Arkeologi Kepulauan Tanimbar: Hasil Penelitian 2011-2014 dan Arah Pengembangannnya. Naditira Widya, 10(1), 1-12.

Schofield, J. (2008). Heritage Management, Theory and Practice. In G. Fairclough, R. Harrison, J. H. Jameson, \& J. Schofield (Eds.), The Heritage Reader (p. 25). London: Routledge.

Sedyawati, E. (2007a). Strategi kebudayaan dalam Kaitan dengan Beberapa Pokok Permasalahan Budaya. In KeIndonesiaan dalam Budaya: Buku 1 Kebutuhan Membangun Bangsa yang Kuat. Jakarta: Wedatama Widya Sastra.

Sedyawati, E. (2007b). Jati Diri Budaya dan Pendidikan Formal. In KeIndonesiaan dalam Budaya: Buku 1 Kebutuhan Membangun Bangsa yang Kuat. Jakarta: Wedatama Widya Sastra.

Spriggs, M., \& Miller, D. (1988). A Previously Unreported Bronze Kettledrum from the Kai Islands, Eastern Indonesia. Bulletin of the Indo-Pacific Prehistory Association, 8, 79-89.

Spriggs, M. (1998). Research Questions in Maluku archaeology. Cakalele, 9(2), 49-62.

Spriggs, M., O'Connor, S., \& Veth, P. (2005). The Aru Islands in Perspective: A General Introduction. In S. O'Connor, M. Spriggs, P. Veth (Eds.), The Archaeology of Aru Island, Eastern Indonesia. Canberra: Pandanus Books.

Tanudirjo, D. A. (1995). Theoretical Trends in Indonesian Archaeology. In P. J. Ucko (Ed.), Theory in Archaeology, A World Perspective (pp. 61-75). London: Routledge.

Tanudirjo, D. A. (1996). Arkeologi Pasca Modernisme untuk Direnungkan. Makalah Pertemuan Ilmiah Arkelogi VII.

Tanudirjo, D. A. (2000). Reposisi Arkeologi dalam Era Global. Buletin Cagar Budaya, 1(2), 11-26.

Tanudirjo, D. A. (2003). Warisan Budaya Untuk Semua: Arah Kebijakan Pengelola Warisan Budaya Indonesia di Masa Mendatang. In Kongres Kebudayaan V (pp. 19-23). Yogyakarta: Universitas Gadjah Mada.

Zuhdi, S. (2006, September 8). Mengapa Bukan Pulau Terdepan. Kompas, p. 7. 